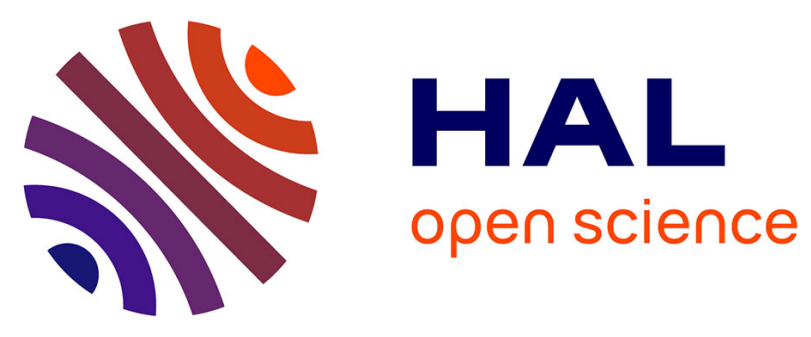

\title{
The Planning of Smart City to Mitigate the Impacts of Natural Disaster in North Sumatera
}

\author{
Dedy Hartama, Herman Mawengkang, Muhammad Zarlis, Rahmat Widia \\ Sembiring, Benny Benyamin Nasution, M. Syahruddin, Prayudi Nastia, \\ Abidin Lutfhi Sembiring, Nogivenname Saifullah, Eka Irawan, et al.
}

\section{To cite this version:}

Dedy Hartama, Herman Mawengkang, Muhammad Zarlis, Rahmat Widia Sembiring, Benny Benyamin Nasution, et al.. The Planning of Smart City to Mitigate the Impacts of Natural Disaster in North Sumatera. 1st International Conference on Information Technology in Disaster Risk Reduction (ITDRR), Nov 2016, Sofia, Bulgaria. pp.147-154, 10.1007/978-3-319-68486-4_12 . hal-03213128

\section{HAL Id: hal-03213128 \\ https://hal.inria.fr/hal-03213128}

Submitted on 30 Apr 2021

HAL is a multi-disciplinary open access archive for the deposit and dissemination of scientific research documents, whether they are published or not. The documents may come from teaching and research institutions in France or abroad, or from public or private research centers.
L'archive ouverte pluridisciplinaire HAL, est destinée au dépôt et à la diffusion de documents scientifiques de niveau recherche, publiés ou non, émanant des établissements d'enseignement et de recherche français ou étrangers, des laboratoires publics ou privés. 


\title{
The Planning of Smart City to Mitigate the Impacts of Natural Disaster in North Sumatera
}

\author{
Dedy Hartama ${ }^{1,3}$, Herman Mawengkang ${ }^{3}$, Muhammad Zarlis ${ }^{3}$, \\ Rahmat Widia Sembiring ${ }^{2}$, Benny Benyamin Nasution ${ }^{2}$, M. Syahruddin ${ }^{2}$, \\ Prayudi Nastia ${ }^{1}$, Abidin Lutfhi Sembiring ${ }^{3}$, Saifullah ${ }^{1}$, Eka Irawan ${ }^{1,3}$, and Sumarno ${ }^{1,3}$ \\ ${ }^{1}$ STIKOM Tunas Bangsa Pematangsiantar, Indonesia \\ ${ }^{2}$ Politeknik Negeri Medan, Indonesia \\ ${ }^{3}$ Universitas Sumatera Utara, Indonesia \\ dedyhartamaeamiktunasbangsa.ac.id
}

\begin{abstract}
This article introduces the smart urban planning in the mitigation of natural disasters in urban areas in Indonesia especially North Sumatera. A smart city is a city-based social development, capital, citizen participation, transportation and information technology, natural resources and quality of life. Frequency and socio-economic impacts of natural disasters frequent in recent decades due to climate change and the environment. The approach used in this paper is a combination of Geographic Information System (GIS) and mobile IT in the form of geospatial information. Mobile services sector in which the city government is involved in the formation of smart cities. This article reviews the growth of smart cities and considers how a systems can improve mitigation and adaptation approaches to these risks and to recovery from the natural disasters.
\end{abstract}

Keywords: Smart City, GIS, Mobile IT, Natural Disasters, Mitigation.

\section{Introduction}

Climate change is happening derived from natural processes and human activities. The increase in temperature of the earth, the sea surface, natural temperature variability and global warming led to a dry, crop failure, disturbed ecosystems, water scarcity, degradation of biodiversity, forest fires, and disease. Climate change is part of the economic problems [1]. Activity detects natural disasters are a disaster management [2]. A natural disaster has become a serious problem in urban areas around the world due to worsening ecological factors tend intensified heat effect and global warming [3]. Carbon reduction potential for the buildings and transport [4]. Potential changes are transformative in the decision-making role of disaster risk management [5].

While in Indonesia, natural disasters were recorded until the month of August 2016 is the number of effects for 1512, the dead and missing totaled of 322 people, victims suffer and displaced as many as 2,086,769 inhabitants and the level of damage caused by the disaster as many as 21,537 residential units [6]. Flood disaster was recorded as the highest $31.4 \%, 20.5 \%$ climate change and landslides $16.7 \%$ and followed by various other natural disasters. Data from the years 1815-2015 in the province of North Sumatra 
recorded deaths totaled to 2,078 people, missing totaled of 234 people, wounded amounted to 29,206 people, and displaced as many as 332,924 people. From the above data, it is necessary to natural disaster risk management plan to minimize the number of victims affected, especially to build smart city.

Smart cities are meant to be able to handle or reduce unexpected natural disasters through high efficiency. Process optimisation of resources, energy supply, waste management, mobility and urbanisation and population growth. Comprehensive intelligent city model that includes all activities related to natural disasters while keeping the size and complexity of the model is maintained very desirable in order to successfully meet the increasing energy needs of a city of the present and future [7]. Various measures of disaster management and planning have been shown to enhance the emergency management capacity and reduce vulnerability to natural hazards [8].

A smart city is a city-based social development, capital, citizen participation, transportation and information technology, natural resources and quality of life. This understanding is based on a deterministic technology from the control room to the city, providing an overview of the architecture and technology-based information on all activities in the city as well as tools to interact with the infrastructure or adjusting the optimal parameters that have been set [9]. While people around the world have had some degree of adaptation to disaster nonetheless there are a number of victims is likely to increase over time. Effect of an urban morphology affects the size of the resulting impact of the disaster eg slope of the land, the location of the geographic area of climate and other factors. Increasing population, the density of buildings and population activities directly impact the disaster [1], for improve decentralised governance of natural disaster need extra effort in highlighting the responsibilities and the role of local government as a key unit in disaster management [10].

In some cities that have a large area tend to be dependent on the government, the system changes involving related parties, strengthening the city's drainage systems, building walls of urban disaster and others [11]. According to the actual facts and new data sources, the gap increases the risk of misuse of information due to limitations of mobile data sources are not well understood. Opportunities for improving disaster management does not guarantee the benefits of the data resulted in less recognised. In helping to address gaps in the use of technology, opportunities, limitations and constraints disaster context [5].

Smart city planning system is the use of a sensor generated data and analysis purposes when decision-making. The resulting smart city government authorities can analyse the data future disasters [12]. The main challenge of how spatial data network can be used to build a smart city based technologies in disaster risk management. Increasing the efficiency of the smart city can be done by providing data related to air temperature, discharge rain, humidity, pressure, wind speed and height of water [12].

This article reviews the growth of smart cities and considers how a systems approach can improve mitigation and adaptation approaches to these risks and to recovery from the natural disasters. 


\section{Importance of Smart City Disaster Planning}

Researchers and scientists have proposed an approach to sustainable urban planning and development. Limit physical growth of uncontrolled exploitation of resources and the need for alternatives. The resulting potential associated with big data, networks, and urban planning. Innovation smart city starts with thinking metabolism urban, produce citizenship intelligent, strengthen human capital, develop collective intelligence of society, facilitating the needs of the population, and the individual gains derived [13] from the availability of new technologies, cities that adopt smart city solutions and communications and information technology organizations usually develop and provide solutions to the technology [14].

Development and population growth in urban areas exacerbate the risk of a possible severity and frequency of natural disasters due to climate change. The need for a strategy to limit the impact of disasters and reduce the possible consequences of a much larger [15] and more destructive in the future. Factors increasing residential population and growing, demanding to be sensitive and prepared to natural disasters such as typhoons and hurricanes, earthquakes, tsunamis, floods, droughts, and forest fires. Climate change can create extreme weather conditions with consequent damage to property and human safety [16].

Simulation of emergencies of natural disasters is essential to minimize the losses, damage and build the resilience of the population. The distribution of emergency resources immediately following the disaster, the need for access to relief agencies information about the magnitude of the disaster, the affected location, characteristics and population dynamics, as well as the distribution of aid resources and infrastructure [5]. In addition, information security for the smart city-related to personal privacy or autonomy of individuals such as secret copyright, patent or trade needs to be enhanced where the information is used to control the system from the electrical grid to medical care when a disaster [17] occurs is very important. Integration of policy always happens at a regional and national level and not at the local level. The area may often be a more relevant scale to address and manage the issues of climate change [18].

The number of institutions responsible for disaster management reduces the effectiveness of disaster management, including the Ministry of Environment (provides guidance on the rules and not national regulations); the regional council (responsible for policy frameworks or regional scale catchment area); territorial authorities (city and county councils are responsible for a particular land use and decision); a group of civil defense emergency management (disaster preparedness and response); and group life line engineering (infrastructure management), hold the responsibility for free. Cooperation between the agency for very important in the flow line and a national holistic approach to natural disaster planning [19]. Urban authorities need to prepare a plan for urban disaster risk management to improve disaster resilience and developing an institutional framework that is effective in improving the resilience of cities and climate change adaptation. Early warning of disasters and geographical mapping needs to be undertaken before natural disaster strikes. Gaps rate of urban growth with the provision of services is increasing rapidly. The city government has set up a disaster management 
plan, creating early warning systems, emergency response mechanisms, capacity building, disaster, climate change, mitigation, evacuation plans, early recovery systems, and coordination of government agencies [20].

Lack of data information in the event of a disaster can lead to slow access, ineffective and negligent in post-disaster recovery. Decision-making and recovery phase of the response can be strengthened the level of vulnerability for the prevention and preparedness phase of the cycle where data management can support disaster management. Big data actively and passively generated through mobile phone communication that attention from the academic and human population is a source of data that is underutilized in disaster management [5]. Results showed of human learning and applicationcentric still put a secondary focus on data preparation and exploration of the impact of disasters [21].

\section{Smart City Disaster Scenario}

The approach used in this paper is a combination of Geographic Information System (GIS) and mobile IT [15] in the form of geospatial information. Geospatial information is a geospatial data that has been processed and can be used to facilitate the planning, decision-making, and activities that are relevant to the location detected natural disasters. Development of geospatial information useful to survey the land such as photogrammetry, remote sensing using very high-resolution satellite imagery, and mapping [22] (see Fig. 1.).

\section{Discussion}

Urban residents worldwide are already depressed because of social and political instability, urbanization, and migration [23] in which the greater frequency of natural disasters. Lifestyle threatens greater impact of natural disasters and residents should consider opportunities through science and technology. The most important projects to government develop local is natural disaster mitigation interventions [24] such as the provision of open land and buildings where the high evacuation can accommodate many people.

Mitigation is a series of efforts to reduce disaster risk, either through physical development as well as awareness and capacity building is facing the threat of disaster. The program aims to reduce or even avoid the impact of catastrophe risk posed by natural disasters. Either before, during and after the disaster. A structured approach to managing uncertainty related to a threat; a range of human activities including risk assessment, developing strategies to manage and mitigate disasters. Basic engineering and natural sciences are essential examined in disaster mitigation planning. In addition, the traditional focus on technology solutions in the life of society affect the evacuation in the event of natural disasters such as outreach to the community about the dangers and help disaster victims. Event organizing and managing a wide range of humanitarian issues related to disaster mitigation in a planned, concerted, integrated, and sustainable so that it becomes an ideal formula in solving various problems of the disaster in the national 
and local scales. The role of communities in disaster mitigation training and community-based and region-based and disaster preparedness and (flood preparedness training, fire preparedness training, eruption preparedness training, earthquake preparedness training).

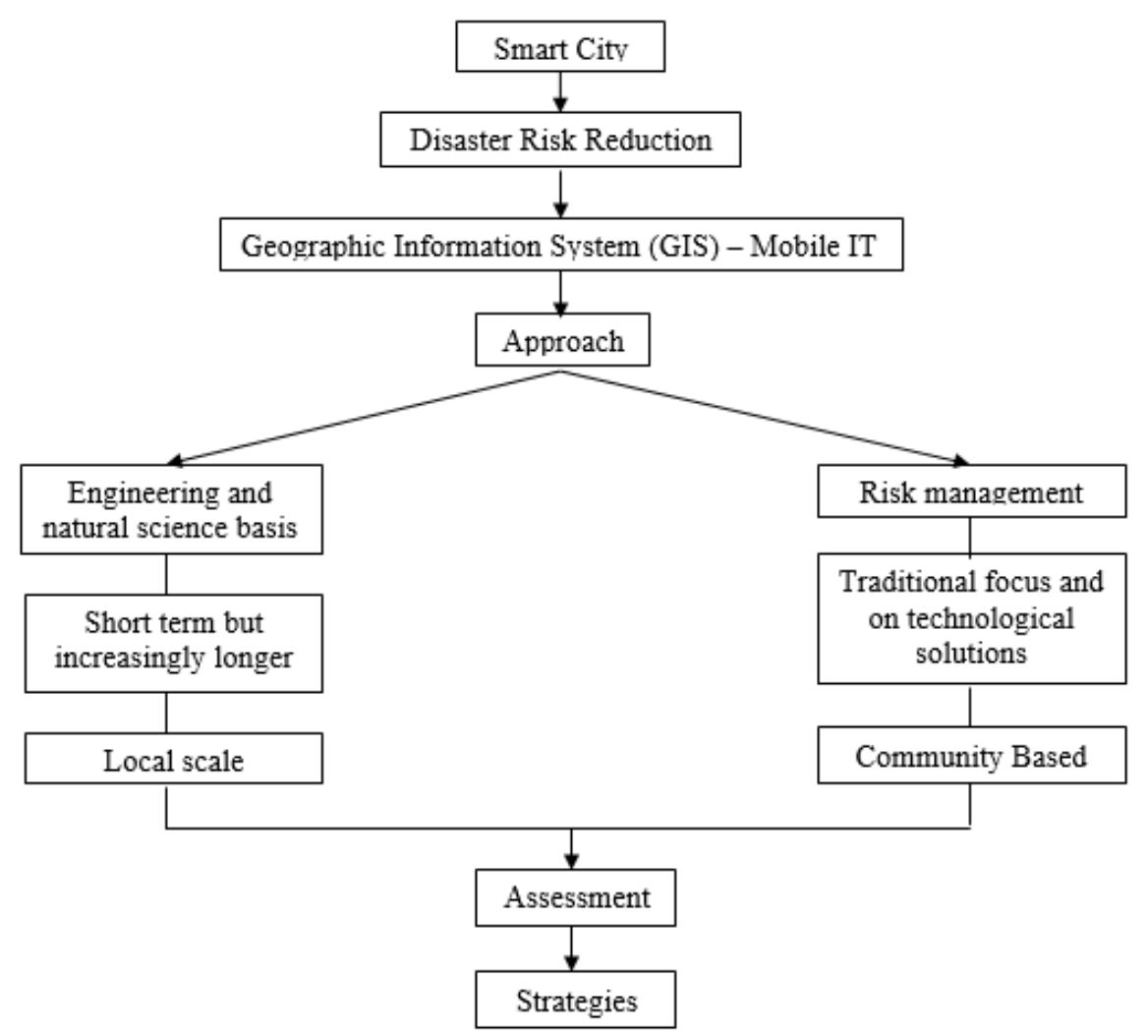

Fig. 1. Smart city system implementation scenario based GIS-mobile IT

Smart urban planning provides support for collective action in the evacuation of a natural disaster. Mobile-GIS provides a real-time visualization of spatial risk and resources as well as analyzing the evacuation routes to safe areas. People are expected to know the evacuation routes via social media platforms and twitter. Formulation of dynamic decision support system that transmits data to a place where the population is a social media network for the detection, mitigation, and the resilience of the population against the dangers of natural disasters [25]. Smart urban planning technologies that are environmentally friendly planning a collaboration of agencies involved in the planning process, for example through integration, the division information, and reach the space environment interact city [26].

Smart cities can be built using the data network system in spreading the sensor. Willingness is the most important dataset of data floods that have occurred in worldwide, 
the temperature of the smart home, vehicles, vehicle parking, pollution, social media, weather and other data [12]. Several approaches need directing for smart city development of equipment and infrastructure facilities. Smart city as a whole can contribute to improving mitigation of natural disasters that can help in situations where policymakers plan proposing methods of cooperative and effective technologies [27].

The main challenge in the development of smart cities is the analysis of real data to make actions [12]. Benefits of building smart cities not only provide benefits to government authorities, but it can help people to guard against disasters and manage them efficiently to achieve the objectives. Natural disaster preventive measures, residents can determine the threshold level of a type of natural disaster has been designated a city. If the predetermined limit then a warning or a warning signal is transmitted to the public through social media [12]. The concept of disaster or hazard mitigation is one way of tackling the rising costs of disaster impacts across the world. Mitigation strategies identified and implemented in an attempt to prevent or minimize harm to the social system, economy, and ecology [28]. Adaptation to climate change is a method for the reduction and prevention of natural disasters. Disaster management and adaptation depending on the role of local government how to establish a policy, plan or program flood management, information and awareness to the community, and flood response [29]. Hazard perception is determined factors of age, education and income, but it depends on a number of factors such as the intensity and frequency of occurrence, the extent of damage to the population and its assets, experience, tradition and way of natural phenomena is recognized [30].

Natural disasters around the world have an impact on public safety and welfare of the urban economy is mainly due to global warming and climate change. Develop techniques in assessing the impact of natural disasters comprehensively and systematically allow nothing extra to catastrophic events [31]. The source of electric power and infrastructure is part of the backbone of modern society. Potential climate change impact and put a low probability on natural disasters Development systems are designed and operated to be reliable under conditions of normal and abnormal [32] should be increased, especially in areas prone to natural disasters due to factors geography.

The sensor system can generate large data disaster data, people, environment, and so on from the smartphone device has great potential to transform urban communities [33]. Social media is consumed by the public can submit relevant information to the spatial characteristics such as geographical information and social hotspot locations. In the event of natural disasters, seismic waves take to propagate away from the epicenter could serve as an early warning system for large-scale incidents. The system was built to predict the mobility of the population or evacuations in various municipalities affected by the disaster can inform disaster management strategy in the future [33]. However, the shortcomings of this system are that if there is an error of the transmitter Global Positioning System (GPS) alone. 


\section{Conclusion}

Big data sensor system in urban environments and applications for monitoring and disaster management using statistical analysis techniques and the major challenges in the development of smart cities is the analysis of real data to make actions. Benefits of building smart cities not only provide benefits to government authorities, but it can help people to guard against disasters and manage them efficiently to achieve the objectives. The sensor system can generate large data disaster data, people, environment, and so on from the smartphone device has great potential to transform urban communities via social media is consumed by the public can submit relevant information to the spatial characteristics such as geographical information and social hotspot locations. In the event of natural disasters, seismic waves take to propagate away from the epicenter could serve as an early warning system for large-scale incidents. The system will built to predict the mobility of the population or evacuations in various municipalities affected by the disaster can inform disaster management strategy in the future.

\section{References}

1. Gravitiani, E., Antriyandari, E.: Willingness to pay for climate change mitigation : application on big cities in Central Java, Indonesia. Procedia - Social and Behavioral Sciences 227 (November 2015), 417-423 (2016).

2. Goswami, S., Chakraborty, S., Ghosh, S., Chakrabarti, A.: A review on application of data mining techniques to combat natural disasters. Ain Shams Engineering Journal (2016).

3. Yamashita, S., Watanabe, R., Shimatani, Y.: Smart adaptation to flooding in urban areas, vol. 118, pp. 1096-1103 (2015).

4. Adil, A. M., Ko, Y.: Socio-technical evolution of Decentralized Energy Systems : A critical review and implications for urban planning and policy. Renewable and Sustainable Energy Reviews 57, 1025-1037 (2016).

5. Cinnamon, J., Jones, S. K., Adger, W. N.: Geoforum Evidence and future potential of mobile phone data for disease disaster management. Geoforum 75, 253-264 (2016).

6. Disaster Statistic of Badan Nasional Penanggulangan Bencana (BNPB). Laporan Pusat aata Informasi dan Humas - BNPB, Jakarta (2016).

7. Calvillo, C. F., Villar, J.: Energy management and planning in smart cities. Renewable and Sustainable Energy Reviews 55, 273-287 (2016).

8. Rumbach, A.: Decentralization and small cities : Towards more effective urban disaster governance? Habitat International (2016).

9. Walravens, N.: Qualitative indicators for smart city business models : The case of mobile services and applications. Telecommunications Policy, pp. 1-23 (2015).

10. Bae, Y., Joo, Y., Won, S.: Decentralization and collaborative disaster governance : Evidence from South Korea. Habitat International, pp. 1-7 (2015).

11. Yamashita, S., Watanabe, R., Shimatani, Y.: Smart adaptation activities and measures against urban flood disasters. Sustainable Cities and Society (2016).

12. Rathore, M. M., Paul, A., Ahmad, A., Rho, S.: US CR. Computer Networks, (2016) 
13. Battarra, R., Gargiulo, C., Pappalardo, G., Boiano, D. A., Smeralda, J.: Planning in the era of Information and Communication Technologies. Discussing the "label : Smart" in SouthEuropean cities with environmental and socio-economic challenges. JCIT 59, 1-7 (2016).

14. Paroutis, S., Bennett, M., Heracleous, L. Technological Forecasting \& Social Change a strategic view on smart city technology : The case of IBM Smarter Cities during a recession. Technological Forecasting \& Social Change (2013).

15. Forino, G., Meding, J. Von, Brewer, G., Gajendran, T.: Disaster risk reduction and climate change adaptation policy in Australia. Procedia Economics and Finance 18 (September), 473-482 (2014).

16. Steiner, F.: Landscape and Urban Planning Frontiers in urban ecological design and planning research. Landscape and Urban Planning 125, 304-311 (2014).

17. Elmaghraby, A. S., Losavio, M. M.: Cyber security challenges in Smart Cities: Safety , security and privacy. Journal of Advanced Research 5(4), 491-497 (2014).

18. Heidrich, O., Reckien, D., Olazabal, M., Foley, A., Salvia, M., Hurtado, S. G., Tiwary, A.: National climate policies across Europe and their impacts on cities strategies. Journal of Environmental Management 168, 36-45 (2016).

19. Saunders, W. S. A., Kilvington, M.: Innovative land use planning for natural hazard risk reduction: A consequence-driven approach from New Zealand. International Journal of Disaster Risk Reduction 18, 244-255 (2016).

20. Shaw, R., Surjan, A., Parvin, G. A.: Urban Disasters and Approaches to Resilience (2016).

21. Granell, C., Ostermann, F. O.: Computers, Environment and Urban Systems Beyond data collection : Objectives and methods of research using VGI and geo-social media for disaster management. CEUS, pp. 1-13 (2016).

22. Sutanta, H., Aditya, T., Astrini, R.: Smart City and Geospatial Information Availability , Current Status in Indonesian Cities. Procedia - Social and Behavioral Sciences 227 (November 2015), 265-269 (2016).

23. Harrison, C. G., Williams, P. R.: Simulation Modelling Practice and Theory A systems approach to natural disaster resilience. Simulation Modelling Practice and Theory 0, 1-21 (2016).

24. Tironi, M., Farías, I.: Geoforum Building a park, immunising life : Environmental management and radical asymmetry. Geoforum, pp. 1-9 (2015).

25. Ai, F., Comfort, L. K., Dong, Y., Znati, T.: A dynamic decision support system based on geographical information and mobile social networks : A Model For Tsunami Risk Mitigation In Padang , Indonesia, Safety Science (2015).

26. Yeo, I., \& Yee, J.: Automation in Construction Development of an automated modeler of environment and energy geographic information (E -GIS) for ecofriendly city planning. Automation in Construction (2016).

27. Kobayashi, T., Ikaruga, S.: Development of a smart city planning support tool using the cooperative method. Frontiers of Architectural Research 4(4), 277-284 (2015).

28. Pine, J. C.: Enhancing the Resilience of Coastal Communities : Dealing with Immediate and Long-Term Impacts of Natural Hazards. Treatise on Estuarine and Coastal Science, vol. 12, Elsevier Inc. (2011).

29. Ghozali, A., Benny, R., \& Ulfa, B.: A Comparative Study of Climate Change Mitigation and Adaptation on Flood Management Between Ayutthaya City ( Thailand) and Samarinda City (Indonesia). Procedia - Social and Behavioral Sciences, 227 (November 2015), 424-429 (2016).

30. Nedelea, A.: Floods and public perception on their effect . Case Study: Tecuci Plain (Romania), year 2013, 32, 190-199 (2016). 
31. Abaker, I., Hashem, T., Chang, V., Badrul, N., Adewole, K., Yaqoob, I., Chiroma, H.: The role of big data in smart city. International Journal of Information Management 36 (5), 748-758 (2016).

32. Espinoza, S., Panteli, M., Mancarella, P., Rudnick, H.: Multi-phase assessment and adaptation of power systems resilience to natural hazards. Electric Power Systems Research 136, 352-361 (2016).

33. Ang, L., Phooi, K.: Big Data Research Big Sensor Data Applications in Urban Environments. Big Data Research 1, 1-12 (2016). 